\title{
Thermal imaging diagnostics locomotives
}

\author{
Andriy Sumtsov ${ }^{1, *}$, Anatoliy Falendysh ${ }^{1}$, and Olha Kletska ${ }^{1}$ \\ ${ }^{1}$ Ukrainian State University of Railway Transport, Department of Thermal Engineering and Heat \\ Engines, Square Feuerbach 7, 61050, Kharkov, Ukraine
}

\begin{abstract}
The work considers the application of thermal imaging control in the operation of diesel locomotives. In particular, the diagnosis of electrical systems, cooling systems and compressors is considered. The results of the thermal imaging control of locomotives of the locomotive series CHME3 are presented. The directions of further researches for increase of efficiency of application of thermal imagers at diagnostics of a condition of systems and units of diesel locomotives are formulated.
\end{abstract}

\section{Introduction}

Continuous improvement of locomotives and increasing the degree of automation of internal control processes put the problem of optimal organization of technical operation at the forefront. An important role in this case is given to the technical condition of the locomotive, which, under the influence of external and internal factors, changes over time. Timely and complete information on the state of the ship together with the forecasting of its change will allow the locomotive to be use more efficiently, taking into account the requirements of traffic safety and the timely delivery of the cargo.

Determination of the technical condition of the locomotive carried out by various means of technical diagnostics. These include stationary systems, onboard built-in systems and portable diagnostic tools. The latter allow for diagnostic operations on locomotive by trained and qualified personnel.

The active development of science and electronics over the past decades has enabled the introduction of new types of diagnostic equipment to a wide extent into the production process of operation and repair of locomotives. Among these varieties of diagnostic devices and complexes are the means of thermal and thermal imaging control. All of them represent a group of means of non-destructive control of the state of nodes and systems that use as a diagnostic feature the temperature and its change.

Let's consider more detailed directions of application of thermal imaging control for diagnostics of knots and systems of locomotives.

Historically, the first units of the rolling stock, which were massively subjected to thermal control, were the rolling units of rolling stock. Various stationary and portable instruments for measuring infrared radiation were using for this purpose. With the advent of thermal imagers, it was possible to measure not only individual points, but also the entire surface of the boot knot. Due to this it is possible simultaneously to obtain an image of the temperature gradient of the entire surface to determine the place of damage or overload. In addition to the boot knots, methods of thermal imaging of other chassis units are actively implemented. In particular, brake discs, wheel band bands, motor-axial bearings for sliding and rolling. Active work in this direction is taking place in the USA, Russia. So in $[1,2]$ various constructions of equipment for diagnostics of chassis are considered. In [2], the technology of machine vision is considered, which allows to quickly and automatically control the state of the running gear of the rolling stock. Using a different spectral image

\footnotetext{
* Corresponding author: gurao@ukr.net
} 
(visible and infrared) allows you to record the physical and thermal state and the correlation between them.

Recently, the use of thermal imaging control for the assessment of the state of electric circuits and electromechanics of rolling stock is actively being carried out. In electrical circuits, the state of the connections is checked. Comparison of individual compounds operating on equal terms allows rapid detection and removal of overheating places without allowing melting, burn-out or damage to current-carrying parts and isolation. This is due to the application of two approaches:

- determination of the absolute temperature of parts and units;

- definition of thermal anomalies in circles and nodes.

The first approach is aimed at obtaining surface temperature data and subsequent calculations for obtaining temperature data in the middle of the node. This approach is used to check the insulation tolerance and the state of the bearing units. In the last significant increase in temperature leads to the leakage of lubricants and, as a consequence, damage to the bearing.

The second approach is used to identify weak and problem areas in electric circuits. It is based on the comparison of the surface temperatures of the electric circuit or the comparison of temperatures of the same type of elements that operate under equivalent conditions. Thus, for example, in [3] the results of the study of the heating of collector plates of traction electric motors are presented. The thermal imaging diagnostics allows to reveal the uneven heating of separate plates and uneven heating of cockroaches compared with the working surface. In this way it is possible to detect low-quality connection of conductors with cockroaches and leakage of solder in the place of soldering. A similar way is the thermal diagnosis of terminal rails and other open connections. As a result, places of high load and low-quality contact, including low-quality soldered connections [3-5], are detected. The latter is a very important factor in preventing failures during operation.

Figure 1 shows the thermogram of the train contactors (a) and the terminal rail (b) CHME3 locomotive. It is clearly visible from the overload of the second train contactor compared to others. In accordance with the existing scheme of electric circuits diesel locomotive CHME3, the distribution of currents on all train contactors are uniform and, as a consequence, their heating should be uniform. The revealed overheating of the second contactor indicates a poor quality contact. In this way, a weak spot identified that requires intervention and regulatory work. As a result, the possibility of a contactor failure due to overheating of the insulation and contact gaps warned. Similarly, the analysis of the condition of the contacts and connections of the terminal rails carried out (Figure $1 \mathrm{~b}$ and Figure 2). It is necessary to take into account the distribution of the load. So on the terminal blocks of diesel locomotives CHME3, the difference in currents provided by the construction can be $50 \%$. Figure 2 shows defects as a contact of terminal block connections due to the insufficient effort of tightening the bolted connection. Thus, the use of test control during the conduct of TO-2 locomotives allows us to assess the state of the contact connections and formulate an operational plan for the regulation and adjustment of electrical contactors and connections.

Relatively new direction of application of thermal imagers is the diagnostics of the fuel system diesel locomotives. As shown by studies [3, 7], the use of thermal imagers allows us to detect malfunctions in the fuel system of high pressure. At the present stage, such a diagnostic can provide advice on the need to repair high-pressure fuel pumps or nozzles depending on the thermal state. 
a)

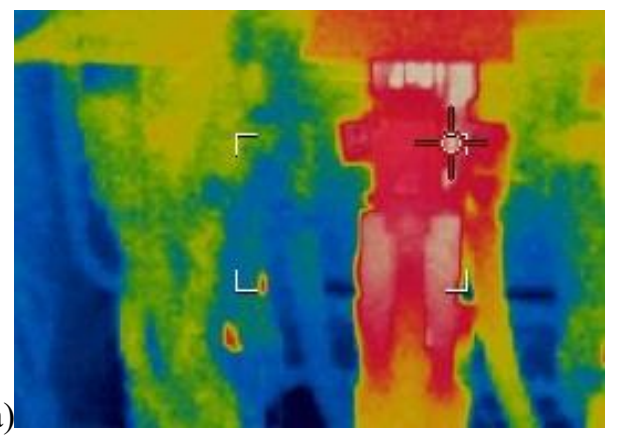

b)

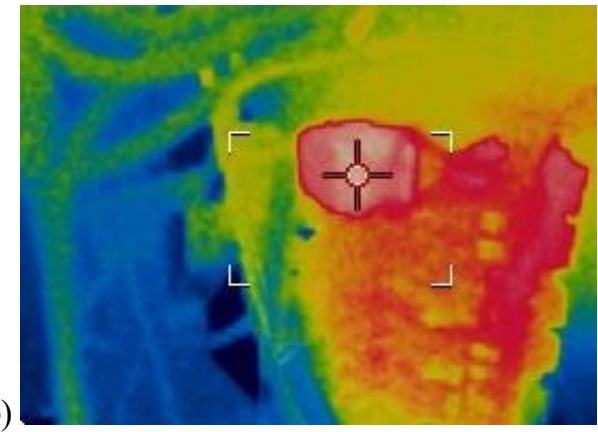

Fig. 1. Termograms of train contactors (a) and terminal rail (b) CHME3 locomotive.
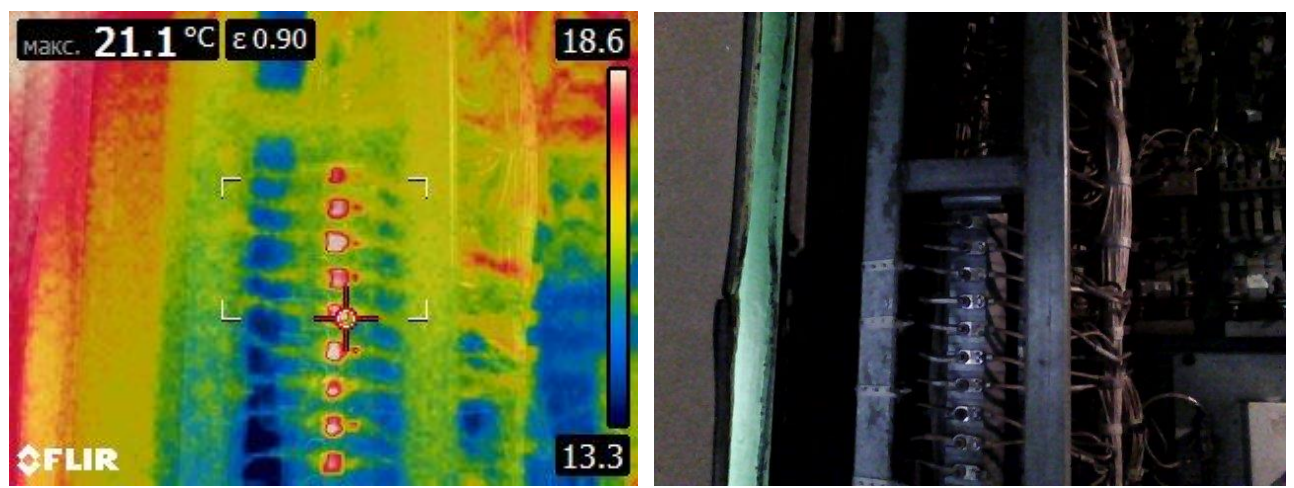

Fig. 2. Thermogram and photo of the terminal rail of CHME3 locomotive.

Thermal diagnostics is actively used to diagnose cooling systems. The main elements of the cooling system of the locomotive, which determine the efficiency of its operation, are the sections of the refrigerator. During operation, the ability of individual sections of the refrigerator locomotives to dissipate heat reduced. Thanks to the use of the thermal imager an express diagnosis of the sections of the refrigerators [3] is carried out. This allows you to adjust the volume of work when cleaning the sections and check the quality of the repairs. Studies $[7,8]$ have proven the feasibility of using thermal sights for the entrance control of the diesel locomotive cooling system when performing repairs and maintenance. Conducting thermo-controlled control of the refrigerator allows the timely detection of sections that do not provide the necessary cooling, and thereby prevent the increase in power take-off on the fan drive. This in turn reduces fuel consumption by $1-1.5 \%$ and does not allow for possible overheating of diesel in operation. This increases the reliability of the locomotive and its fuel efficiency, which makes it possible to reduce costs for the current maintenance of the locomotive as a whole.

Let's consider in more detail the application of thermal imaging diagnostics for technical maintenance and repairs of the cooling system of the locomotive. The thermal imaging technology based on measuring the temperature on the surface of the engine's refrigerating sections with subsequent processing of the results. During processing, temperature, uniformity of section heating and local overheating points are determined. Measurement carried out on a heated diesel locomotive with a stable mode of operation of the cooling system (without changing the temperature of the coolant). Figure 3 shows a thermogram and a photograph of fully functioning sections of the CHME3 diesel engine cooling system. The thermogram clearly demonstrates the uniform heating of all sections and throughout their length. 


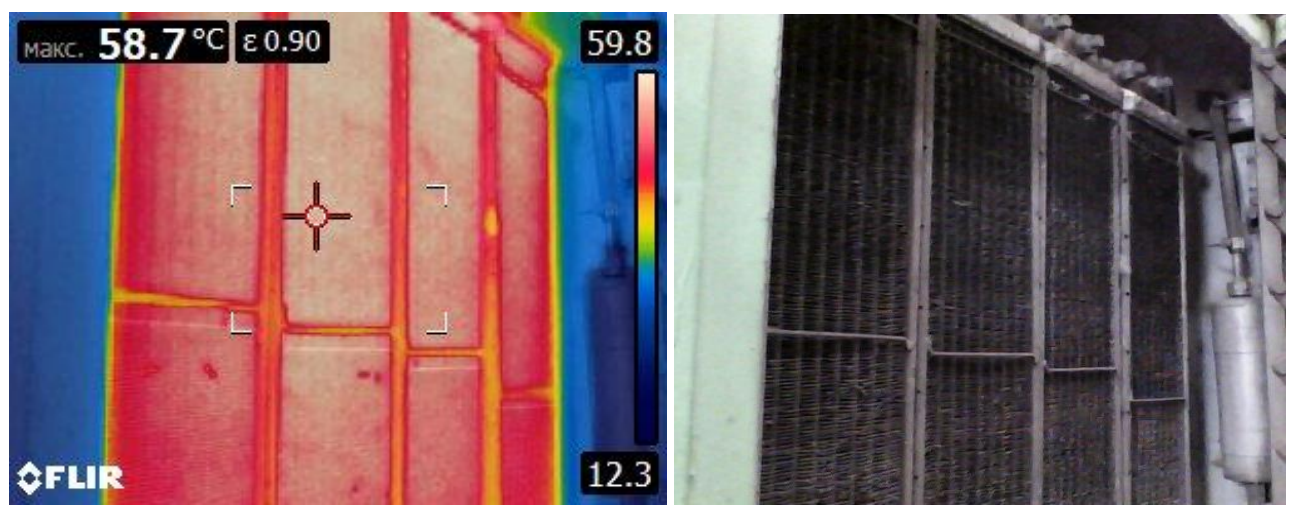

Fig. 3. Thermogram and photograph of the proper sections of the cooling system of the diesel locomotive CHME3.

In the event of worsening of the throughput of the section (due to the contamination of pipes or their drooping), heat transfer is greatly deteriorated. Figure 4 shows sections with uneven heating. So the most distant section is completely muffled and does not pass water. In it only the heating of the upper connecting flange occurs due to heat transfer from the surface of the collector. The two cooling sections located in the middle are dirty tubes. The second section of the arrangement has a slight contamination and the temperature of the drop in the section at $15^{\circ} \mathrm{C}$. The third section has a low passage of tubes and, as a consequence, a drop of $35^{\circ} \mathrm{C}$. Thus, from the four sections, two are required to rinse, one is repair and the first section is operational.
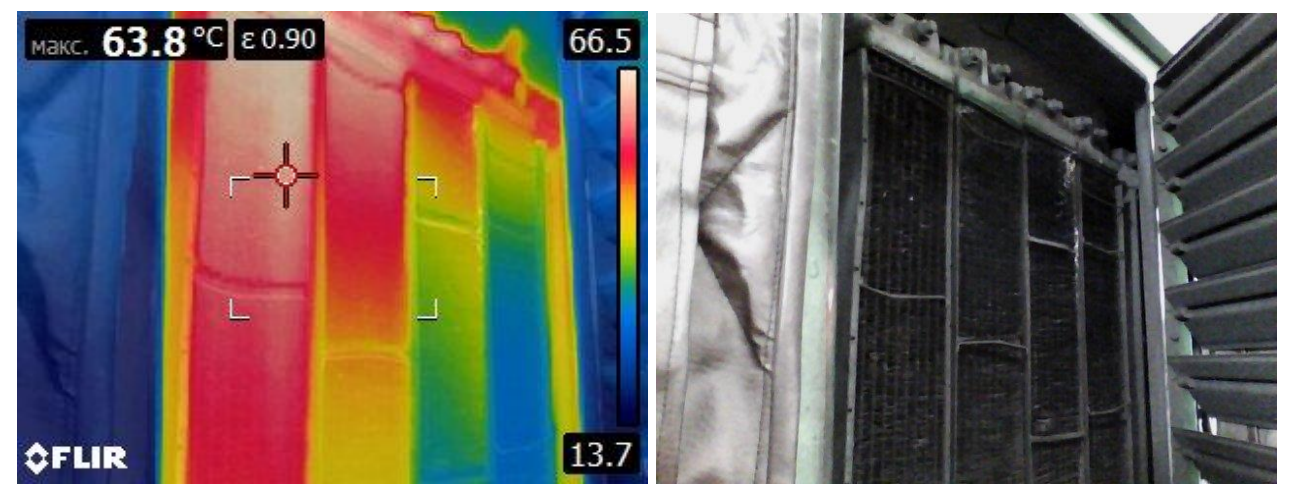

Fig. 4. Thermogram and photograph of the proper sections of the CHME3 diesel engine cooling system.

When using thermal sensors to check the status of sections of refrigerators with a tworow arrangement, it is necessary to check both the internal and external series of sections. Particularly relevant is checking the status of sections of refrigerators when switched to operation in winter conditions. When the cooling fluid passes through the tube, at low temperatures, there is the possibility of freezing sections with subsequent damage due to the expansion of water in the tubes. In order to avoid this phenomenon, locomotives are increasingly using cooling liquids with a low freezing point and a heat storage system.

In addition to the considered method of use of thermal imagers, they can be used for complex diagnostics of the efficiency of the refrigeration unit. Such an approach is proposed in [9]. As a diagnostic parameter, the temperature pressure of the tube wall of the section $\Delta \mathrm{tn},{ }^{\circ} \mathrm{C}$ (between the coolant and the outer surface of the refrigerator sections) is used:

$$
\Delta t_{j}=t-t_{n j}
$$


where:

$\mathrm{t}$ - water temperature at the entrance to the radiator section, $\left[{ }^{\circ} \mathrm{C}\right]$,

tpj - temperature of the tube surface section, $\left[{ }^{\circ} \mathrm{C}\right]$,

$\mathrm{j}$ - section number.
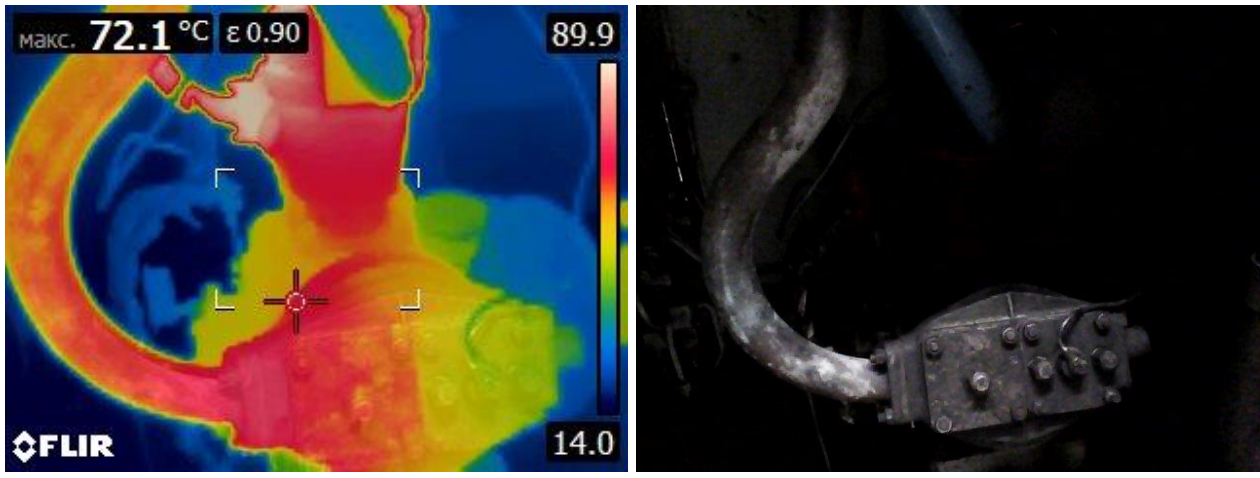

Fig. 5. Thermography and photograph of the compressor K2-Lock.

Refrigerator of the cooling system is subject to inspection in the process of carrying out of rheostats tests of diesel locomotive. This is due to the need for a long measure of temperature at the nominal (full power) mode, in which the greatest amount of heat is allocated to the cooling system. The thermal image of the sections of the sections is removed using the thermal imager. Each thermogram is treated with ten sections for typical sections and the surface temperature tj in each section is determined. Then, by the expression (1), the temperature difference is calculated in each section of the section, the average value of $\Delta \mathrm{tj}$ is determined and compared with the minimum allowable value). In this way, all sections are checked and a general conclusion is drawn about the possibility of cooling the system to dissipate heat from the diesel engine. This way the decision is made on the need to repair the refrigerator locomotive.

An important aspect of using thermal vision is the diagnosis of the state of compressor locomotives equipment. Due to the use of heat shocks, check the quality and uniformity of the valve mechanism, the condition of the bearing units and the radiator of cooling air. Figure 5 shows the work flow diagram of the compressor K2-LOK diesel locomotive CHME3.

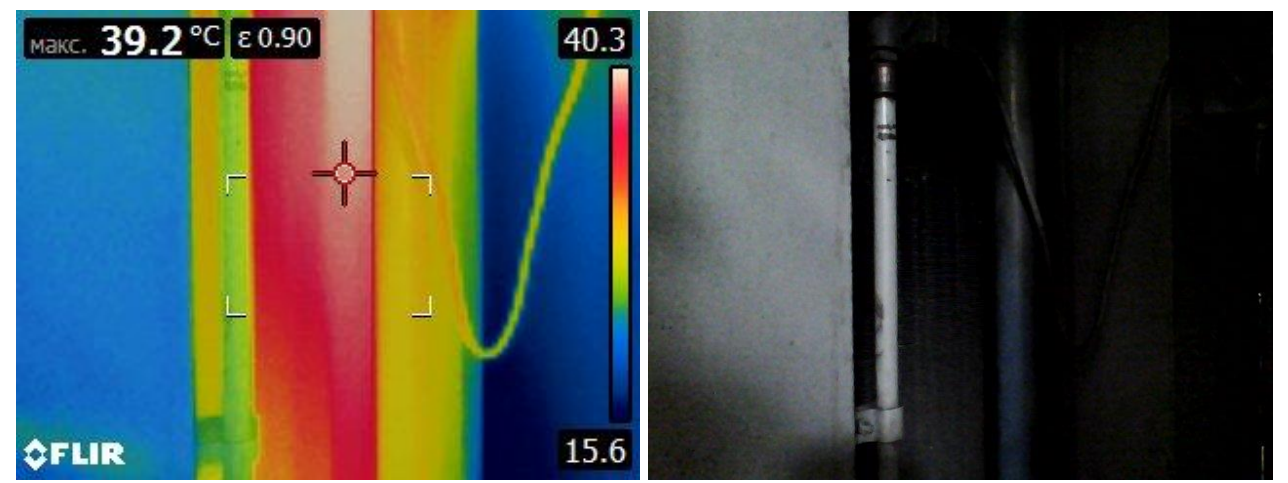

Fig. 6. Thermogram and photo of cooling fan of traction electric motors of locomotive YME3.

The temperature difference in the first degree of compression of air is about $30^{\circ} \mathrm{C}$. This parameter serves as an indirect proof of the normal operation of the compressor valve mechanism and the presence of compression. 
In the same way as thermal inspection of sections of the refrigerator, an intermediate compressor cooler is checked. Figure 6 shows the results of this check. At the same time, the main difference is checking that I will not turn the tubes, but I will get a sharpening and, as a consequence, cooling quality by the flow of air.

The use of thermal imaging controls to diagnose the condition of bearing units has significant prospects. So this type of diagnosis is subject to all electric and auxiliary mannina. For an example, let's consider the results of diagnostics of cooling fan of traction electric motors of diesel locomotive CHME3 shown in Figures 7 and 8.
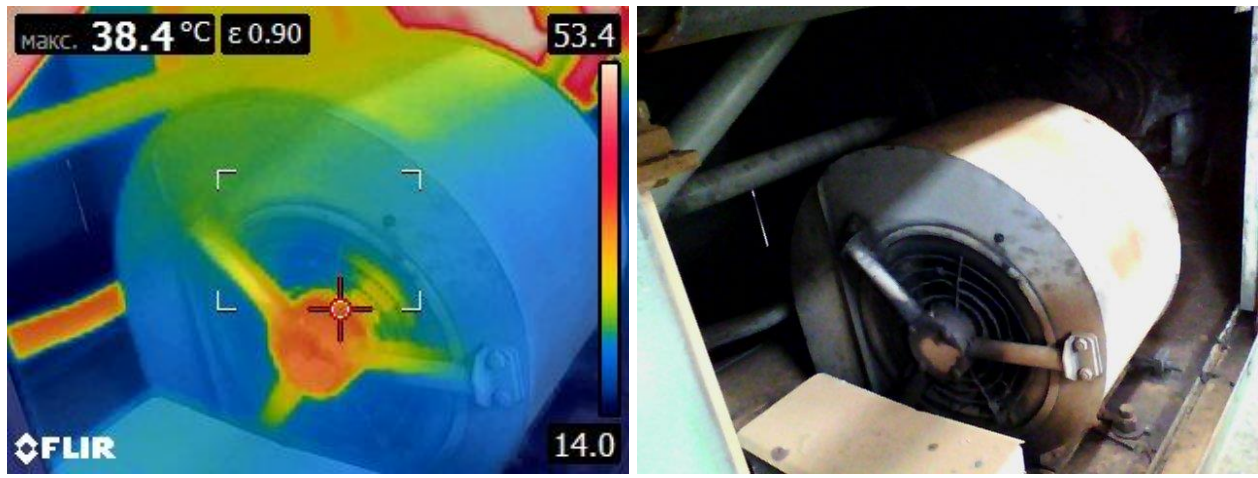

Fig. 7. Thermography and photo of cooling fan of traction electric motors of locomotive ЧME3.

Figure 7 shows the thermal graph of the back cover of the fan. Located in the center of this cover, the roller bearing is a source of heat. Due to the friction that occurs as a result of the fan's operation, a tempo is created. With insufficient lubrication there is a rapid increase in temperature. With too high values there is a leakage of grease lubrication and there is a possibility of jamming of the fan. The given diagram shows a good bearing unit (the heating temperature does not exceed $40^{\circ} \mathrm{C}$ ).
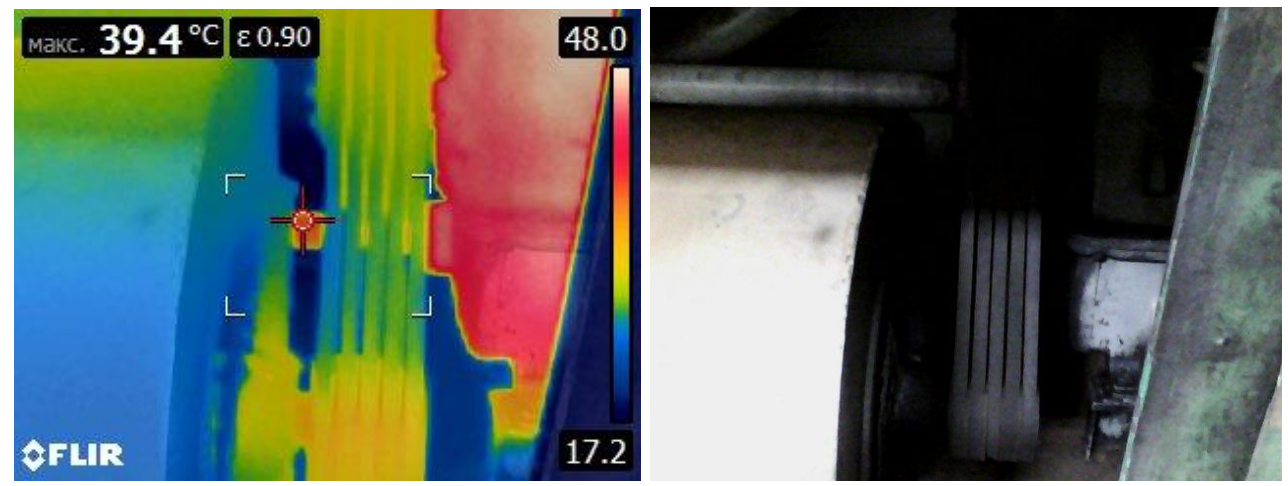

Fig. 8. Termogram and photo of cooling fan of traction electric motors of diesel locomotive CHME3.

Figure 8 represents the front cover of the cooling fan for traction motors. The condition of the bearing unit is similar to the rear. The heating temperature is lower by $10^{\circ} \mathrm{C}$ due to better air cooling.

On the thermogram of Figure 8 it is clearly visible to heat the belts and pulleys of the fan drive. The difference in the temperature of the microfibers of the pulleys clearly demonstrates the intensity of the use of a smaller pulley compared to a larger pulley, which explained by the higher frequency of rotation of the first one. The uniformity of the heating of the belts of the cavalry transmission indicates the correctness and uniformity of their tension. Proceeding from this, the presented thermograms prove the serviceability of the cooling fan of traction electric motors and its drive. 
Another direction of thermal imaging control is to check the amount of fuel and its temperature in the fuel tanks. This direction on locomotives little used because of the presence of standard systems for determining the amount of fuel that has a higher accuracy of measurement compared with the thermal method. An example of such a measurement shown in Figure 9.

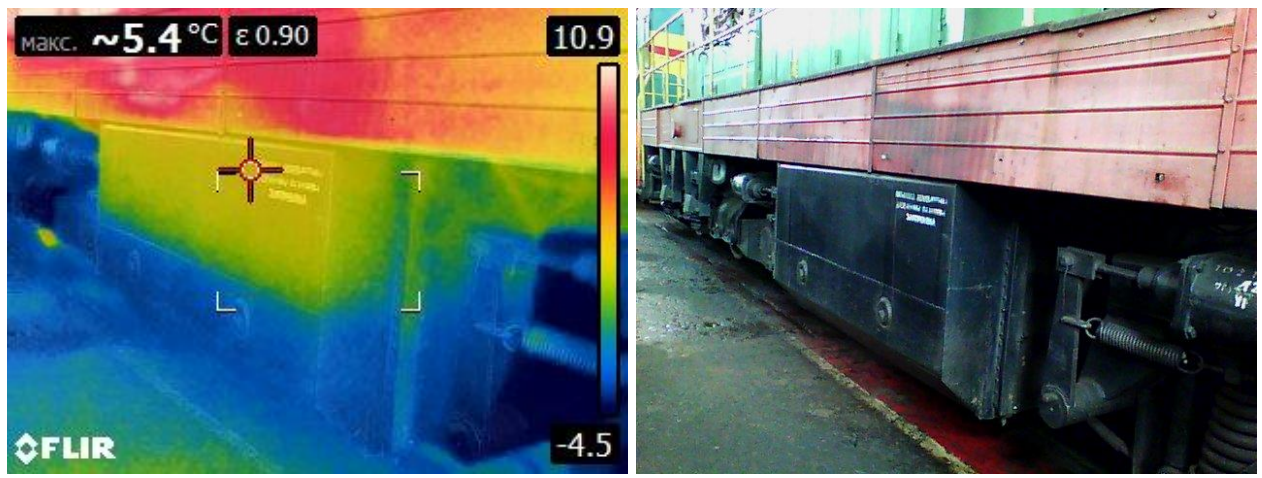

Fig. 9. Thermogram and photo of fuel tank diesel locomotive CHME3.

Thus, the use of thermal imaging control allows operative diagnostics of most nodes and locomotive systems with the detection of places with atypical thermal load. Depending on the equipment tested, after the diagnosis, the site is adjusted or repaired.

The use of thermal imaging diagnostics allows us to implement maintenance and repair on the actual condition of the nodes, which is difficult to verify by other types of diagnostics, for example, the quality of soldering of collector plates, contact in the places of connection of current-carrying parts of electric circuits, etc.

\section{References}

1. Багаутдинов В.Р., Ураксеев М.А. Методы контроля ходовой части железнодорожного транспорта. Тепловизионный метод. [Текст]./ В.Р. Багаутдинов, М.А. Ураксеев / ИЗВЕСТИЯ ВолгГТУ, 2012. - №10 (97). - С. 5 - 10

2. Machine Vision Using Multi-Spectral Imaging for Undercarriage Inspection of Railroad Equipment / J.M. Hart, E. Resendiz, B. Freid, S. Sawadisavi, C.P.L. Barkan, N. Ahuja

3. Овчаренко C.M., Балагин О.В., Балагин Д.В. Реализация комплексной системы бесконтактноготеплового контроля узлов тепловозов. / С.М. Овчаренко, О.В. Балагин, Д.В. Балагин // ИЗВЕСТИЯ Транссиба, 2014. - №4(20). - С. 35 - 40

4. Хачкинаян С.А., Губарев П.В., Рубан В.Г., Матва А.М. Методы тепловизионного контроля электрического оборудования электровозов. - Труды международной научно-практической конференции «ТРАНСПОРТ-2013». - С. 265-265

5. Рубан В.Г. Комплексный подход к организации тепловой диагностики узлов локомотивов в условиях депо / В.Г. Рубан, О.А. Ворон // Труды Всероссийской научно-практической конференции «Транспорт-2011», часть 2. Ростов-на-Дону, 2011.- c. 421-423

6. Боряк К. Ф. Перспективы внедрения температурного мониторинга для диагностики технического состояния механических узлов подвижного тягового железнодорожного состава / К. Ф. Боряк, С. Л. Волков, Е. С. Шпат // Техническая диагностика и неразрушающий контроль. - 2014. - № 2. - С. 50-53

7. Лобанов И. И. Повышение эксплуатационной эффективности тепловозных дизелей применением средств оперативной диагностики. Диссертация на соискание ученой степени кандидата технических наук по специальности 05.22.07 - Подвижной состав железных дорог, тяга поездов и электрификация - Москва, 2017. -209 c 
8. Горин А. В. Контроль технического состояния систем охлаждения тепловозных дизелей - Вестник ВНИИЖТ 3/2015. - С. 23 - 30

9. Анисимов А.С., Балагин О.В., Чулков А.В. Технология тепловизионного контроля технического состояния секций холодильников тепловозных дизелей. - Омский научный вестник, 2006. - №3(36). - С. $111-113$ 